\title{
Peningkatan Kemampuan Siswa Kelas IX SMP Negeri 3 Palopo Menjelaskan Alur Peristiwa Sinopsis Novel Melalui Kegiatan Mendengarkan Dengan Menggunakan Teknik
} Jigsaw

\author{
Miske \\ SMP Negeri 3 Palopo \\ $+62852-9889-6475$
}

\begin{abstract}
Abstrak
Penelitian ini bertujuan untuk meningkatkan kemampuan siswa dalam menjelaskan alur peristiwa dalam sinopsis novel melalui kegiatan mendengarkan dengan menggunakan metode jigsaw, selain itu untuk meningkatkan kemampuan dan keterampilan guru dalam melaksanakan pembelajaran bahasa Indonesia, terutama pembelajaran sastra khususnya unsur intrinsik sinopsis novel. Penelitian ini dilaksanakan terhadap siswa kelas IX SMP Negeri 3 Palopo sebanyak 48 orang. Penelitian ini dilaksanakan pada tanggal 11 Mei 2016 dan pada tanggal 18 Juli 2016. Hasil penelitian ini menunjukkan bahwa kemampuan siswa dalam memahami alur sinopsis novel meningkat setelah dilakukan tindakan pembelajaran dengan menggunakan metode jigsaw dari siklus I hingga siklus II. Guru memotivasi siswa, mengadakan tanya jawab tentang unsur intrinsik, membaca pemamahan, menentukan alur sinopsis novel secara individual, diskusi kelompok, menyimpulkan kegiatan, melaporkan kegiatan, menanggapi dan menulis kembali hasil belajar. Untuk itu, peneliti menyarankan kepada guru agar mau menggunakan pendekatan ini sebagai alternatif pembelajaran memahami unsur intrinsik terutama alur sinopsis novel di SMP. Penggunaan pendekatan ini meliputi motivasi siswa, tanya jawab, membaca pemahaman, menentukan alur sinopsis novel secara individu di kelompoknya, melaporkan hasil diskusi kelompok, menanggapi hasil laporan dan menyimpulkan kegiatan.
\end{abstract}

Kata Kunci: jigsaw, sinopsis novel, menyimak

\section{Pendahuluan}

Keterampilan menyimak merupakan salah satu kegiatan berbahasa yang utama di dunia pendidikan. baik di tingkat taman kanak-kanak, SD, SMP, SMA/SMK maupun perguruan Tinggi. Keterampilan berbahasa erat kaitannya dengan proses berpikir yang mendasari bahasa. Bahasa seseorang mendasari pikirannya. Semakin cerah dan jelas pikiran seseorang semakin terampil seseorang berbahasa. Melatih keterampilan berbahasa berarti melatih keterampilan berpikir (Dawson, 1963:2 7; Tarigan; 1980: 1)

Menyimak merupakan suatu keterampilan berbahasa yang tidak dapat dilepaskan dari kehidupan manusia sehari-hari baik di lingkungan formal, maupun non-formal. Berdasarkan keterangan di atas maka jelas bahwa keterampilan menyimak harus dibina dan ditingkatkan karena sangat dibutuhkan oleh manusia baik untuk kebutuhan sehari-hari maupun untuk kepentingan dilingkungan pendidikan.

Depdikbud (1994: 50) menjelaskan bahwa yang termasuk unsur intrinsik cerita yang perlu diajarkan siswa SMP adalah terra, alur, latar, titik pengisahan, dan penokohan. Alur/plot 
merupakan unsur fiksi yang penting, hal itu beralasan, sebab kejelasan tentang kaitan sebuah cerita akan mempermudah pemahaman kita terhadap cerita yang ditampilkan. Kejelasan plot berarti kejelasan cerita, kesederhanaan plot berarti kemudahan cerita untuk dimengerti. Sebaliknya, plot sebuah karya fiksi yang kompleks, ruwet, dan sulit dikenali hubungan kausalitas antar peristiwanya, menyebabkan cerita menjadi lebih sulit dipahami.

Peristiwa, konflik, dan klimaks merupakan tiga unsur yang amat esensial dalam pengembangan sebuah plot cerita. Eksistensi plot itu sendiri sangat ditentukan oleh ketiga unsur tersebut. Peristiwa dapat diartikan sebagai peralihan dari suatu keadaan ke keadaan yang lain. Konflik adalah sesuatu yang dramatic, mengacu pada pertarungan antara dua kekuatan yang seimbang yang menyiratkan adanya aksi dan aksi balasan (Wellek \& warren, 1989:285). peristiwa dan konflik biasanya berkaitan erat, dapat saling menyebabkan terjadinya satu dengan yang lain.

Konflik dan klimaks merupakan hal yang amat penting dalam struktur plot, keduanya merupakan unsur utama plot pada karya fiksi. Konflik demi konflik, baik internal maupun eksternal, inilah jika telah mencapai titik puncak menyebabkan terjadinya klimaks. Klimaks hanya dimungkinkan ada dan terjadi jika ada konflik. Klimaks, menurut Stanton (1965: 16), adalah saat konflik telah mencapai tingkat intensitas tertinggi, dan saat (hal) itu merupakan sesuatu yang tak dapat dihindari kejadiannya. Artinya berdasarkan tuntutan dan kelogisan cerita, peristiwa dan saat itu memang harus terjadi, tidak boleh tidak. Klimaks sangat menentukan (arah) perkembangan plot.

Pembelajaran menjelaskan alur peristiwa dari suatu sinopsis novel melalui kegiatan mendengarkan telah peneliti lakukan secara klasikal. Dalam pembelajaran ini, pembelajaran masih kurang berhasil, hasil pembelajaran tersebut tidak mencapai kriteria ketuntasan minimal (KKM). Perolehan data hasil refleksi ternyata hanya beberapa siswa yang dapat menjelaskan alur peristiwa sinopsis novel melalui kegiatan mendengarkan.

Bertolak dari kegiatan di atas, guru perlu memberikan respon positif secara konkret dan objektif yang berupa upaya membangkitkan partisipasi siswa dalam memahami serta meningkatkan kemampuan siswa dalam menjelaskan alur peristiwa sinopsis novel. Untuk itulah maka peneliti merasa tertarik untuk meneliti mengenai pemahaman siswa terutama mengenai alur sebuah cerita.

Dari uraian latar belakang yang telah dideskripsikan, maka yang menjadi tujuan penelitian yang akan dicapai adalah meningkatkan kemampuan siswa dalam menjelaskan alur peristiwa dari suatu sinopsis novel melalui kegiatan mendengarkan dengan menggunakan metode jigsaw. Selain itu juga penelitian ini bertujuan meningkatkan kemampuan dan keterampilan guru dalam melaksanakan kegiatan pembelajaran bahasa Indonesia terutama pembelajaran sastra khususnya unsur intrinsik novel.

\section{Metode Penelitian}

Penelitian ini merupakan penelitian tindakan kelas dalam dua siklus yang berfokus pada kemampuan siswa dalam menjelaskan alur peristiwa dari suatu synopsis novel melalui kegiatan mendengarkan dengan menggunakan teknik jigsaw. Dalam setiap siklus terdapat empat fase, yaitu (1) merencanakan PTK, (2) melaksanakan PTK, (3) observasi. (4) refleksi. Keempat fase tersebut direncanakan dan dilaksanakan untuk meningkatkan kemampuan siswa dalam menjelaskan alur peristiwa dari suatu sinopsis novel melalui kegiatan mendengarkan dengan menggunakan teknik jigsaw. 
Kegiatan yang peneliti lakukan dalam merencanakan PTK antara lain, menyusun rencana pelaksanaan pembelajaran (RPP); membuat pedoman observasi sebagai instrument untuk mengumpulkan data tentang proses pembelajaran; dan membuat lembar kerja siswa sebagai yang harus dikerjakan selama proses pembelajaran untuk mengukur tingkat ketercapaian indikator.

Kegiatan pelaksanaan PTK adalah pembelajaran mendengarkan sinopsis novel melalui kerjasama kelompok serta menentukan alur synopsis novel tersebut, berpedoman pada rencana yang telah disusun. Kemudian, observasi atau pengamatan dilakukan oleh dua orang observer terhadap proses pembelajaran yang dilakukan oleh peneliti.

Setelah proses pembelajaran siklus pertama berakhir, refleksi dilakukan bersama kedua observer. Hasil refleksi adalah ditemukannya masalah yang menjadi penghambat peningkatan pemahaman siswa terhadap menjelaskan alur peristiwa dari suatu sinopsis novel.

Pada akhir pembelajaran siklus kedua peneliti melakukan analisis data dengan urutan kegiatan sebagai berikut. Pertama, mereduksi data, kedua, mengorganisasi data, dan ketiga, menarik kesimpulan, (Wardani, 2002:2.18). Mereduksi data adalah kegiatan membuang data yang tidak relevan dan mencatat data yang dapat digunakan untuk membuktikan hipotesis. Mengorganisasi data artinya mendeskripsikan data secara naratif sesuai dengan urutan kegiatan pembelajaran. Menarik kesimpulan adalah kegiatan mengolah data secara kuantitatif dan untuk menarik kesimpulan.

Siklus Penelitian Tindakan Kelas ini akan dilaksanakan pada tanggal 11 Agustus dan Siklus kedua dilaksanakan pada tanggal 18 Oktober 2016 di kelas IX SMP Negeri 3 Palopo Kota Palopo. Subjek penelitian di kelas IX $\mathrm{X}_{\mathrm{b}}$ SMP Negeri 3 Palopo Kota Palopo dengan jumlah siswa 48 orang.

\section{Teknik Pengumpulan Data}

\section{Observasi}

Teknik pengumpulan data yang digunakan dalam penelitian ini adalah observasi dan tes. Pelaksanaan observasi dilakukan bersamaan dengan pelaksanaan perbaikan pembelajaran. Selanjutnya dijelaskan bahwa dimensi-dimensi yang perlu dideskripsikan adalah (1) tampilan fisik siswa dan guru; (2) dialog sebagaimana yang terjadi dalam pembelajaran; (3) lingkungan fisik atau kelas dengan berbagai situasinya atau seting pembelajaran; dan (5) kejadian-kejadian khusus yang dilakukan oleh siswa ketika berinteraksi dengan sumber-sumber belajar; (6) berbagai aktivitas siswa dan guru dalam meng-implementasikan tahapan-tahapan model pembelajaran, serta (7) pikiran dan perasaan peneliti perlu dideskripsikan secara rinci, karena dalam penelitian kualitatif peneliti merupakan bagian dari penelitian.

Tes

Tes yang digunakan adalah tes yang dilakukan oleh siswa setelah proses pembelajaran berlangsung. Tes tersebut merupakan pelaksanaan evaluasi yaitu evaluasi yang dilaksanakan setelah pembelajaran berlangsung. Bentuk tes berupa uraian.

\section{Teknik Pengolahan Data}

Data yang digunakan untuk mengukur tingkat kemampuan siswa menjelaskan alur peristiwa dari suatu synopsis novel melalui kegiatan mendengarkan adalah data dari hasil kerjasama kelompok siklus pertama dan siklus kedua. Karena data tersebut berupa angka, maka teknik 
pengolahan data yang digunakan adalah teknik kuantitatif. Teknik kuantitatif yang peneliti gunakan sebagaimana dilakukan dalam pembelajaran sehari-hari dengan cara sebagai berikut:

1. Peneliti membandingkan prosentasi ketercapaian setiap indikator dari setiap kelompok pada siklus kesatu dengan kedua.

2. Membandingkan prosentasi ketercapaian seluruh indikator dari setiap kelompok pada siklus kesatu dengan siklus kedua.

3. Hasil perbandingan keduanya diubah ke dalam bentuk diagram batang dan diagram lingkaran.

Selisih hasil tes siklus kedua dan siklus pertama merupakan hasil belajar, (Arikunto, 1998:84). Hasil belajar tersebut merupakan peningkatan kemampuan siswa menjelaskan alur peristiwa dari suatu synopsis novel melalui kegiatan mendengarkan Apabila terjadi peningkatan kemampuan siswa dalam mendengarkan cerita, berarti hipotesis terbukti. Atau sebaliknya, jika tidak terjadi peningkatan kemampuan siswa dalam mendengarkan cerita, berarti hipotesis tidak terbukti.

\section{Hasil Penelitian \& Pembahasan}

\section{Siklus I}

Pelaksanaan penelitian tindakan kelas pada siklus I (pertama) ini dilaksanakan pada tanggal 11 Mei 2016 di kelas IX ${ }_{b}$ SMP Negeri 3 Palopo selama dua jam pelajaran. Setiap pertemuan membutuhkan satu Rencana Pelaksanaan Pembelajaran (RPP). Pada siklus I ini, guru mengawali pembelajaran dengan mengkondisikan kelas dan menanyakan kehadiran siswa, kegiatan selanjutnya siswa bertanya jawab tentang unsur intrinsik sinopsis novel, selesai tanya jawab guru membacakan sinopsis novel yang berjudul "Tunjung Biru". Setelah itu guru membagi kelompok yang terdiri dari 9 kelompok. Setiap kelompok terdiri dari 5 sampai 6 orang. Tiap orang dalam tim diberi bagian materi yang berbeda.

Selanjutnya siswa mendengarkan sinopsis novel. Setelah itu siswa membentuk kelompok baru berdasarkan tugas yang sama sehingga menjadi kelompok tim ahli.

1. Tim ahli I membahas tentang pendahuluan.

2. Tim ahli II membahas tentang penampilan masalah.

3. Tim ahli III membahas tentang puncak ketegangan.

4. Tim ahli IV membahas tentang ketegangan menurun.

5. Tim ahli $\mathrm{V}$ membahas tentang penyelesaian.

Selanjutnya dari kelompok yang telah dibagi di awal, siswa yang memperoleh nomor yang sama bergabung untuk membahas materi yang diberikan guru (kelompok ahli). Lalu berdiskusi untuk memperoleh jawaban. setelah Siswa yang tadi bernomor sama (kelompok ahli) berdiskusi, tiap anggota kembali ke kelompok awal dan bergantian mengajar teman satu tim mereka tentang bagian yang mereka kuasai, yang lainnya mendengarkan dengan sungguhsungguh. Selama proses diskusi berlangsung, guru mengamati sambil berkeliling menjaga kemungkinan ada siswa yang masih belum mengerti dan siap untuk memberi penjelasan.

Dalam taraf terakhir guru memfokuskan pembelajaran pada tahap pasca analisis, diantaranya dimulai dengan memberikan pertanyaan ringan yang berkaitan dengan hasil menganalisis unsur intrinsik sinopsis novel, kemudian menyuruh wakil masing-masing kelompok untuk membacakan hasilnya, kelompok lain menanggapi. Pada tahap ini siswa menyimpulkan kegiatan dengan menganalisis kembali hasil diskusi. 
Hasil analisis menjelaskan alur synopsis novel siklus I (pertama) siswa yang mendapatkan perlakuan pembelajaran alur sinopsis novel dengan pendekatan analisis ini berjumlah 48 . Pembelajaran alur synopsis novel siklus pertama di kelas IX pada umumnya belum memuaskan, hal ini dapat terlihat dari siswa yang berjumlah 48 tersebut hanya $56 \%$ yang mencapai nilai Kriteria Ketuntasan Minimal $(7,5)$ sedangkan 44\% masih dibawah KKM.

Refleksi dilakukan bersama-sama dengan kedua observer dengan tujuan untuk menemukan kegiatan-kegiatan yang perlu diperbaiki serta menetapkan solusinya. Perencanaan pembelajaran yang berupa RPP tetap dipertahankan pada siklus berikutnya, skenario pembelajaran yang dituangkan dalam langkah-langkah yang terdapat dalam RPP perlu ditinjau kembali, hal ini perlu dilakukan karena dalam proses pelaksanaan siswa terlihat masih bingung dengan teknik diskusi jigsaw yang diterapkan guru.

Pada tahap awal, dalam memberikan penjelasan mengenai unsur intrinsik novel, terutama alur, sebaiknya guru memberikan contoh dengan cerita yang lain. Masih banyak siswa yang belum paham cara menganalisis alur sinopsis novel, terlihat dari banyaknya siswa bertanya mengenai alur, karena itu untuk tahap berikutnya guru harus memberikan contoh cara menganalisis alur.

Tabel 1. Jumlah Skor Siswa Pada Tiap Tahap Kegiatan Siklus I

\begin{tabular}{llrrrr}
\hline \multirow{2}{*}{ No } & Tahapan & \multicolumn{5}{c}{ Jumlah Skor } \\
\cline { 3 - 6 } & Alur & \multicolumn{1}{c}{3} & 2 & \multicolumn{1}{c}{1} & \multicolumn{1}{c}{0} \\
\hline 1 & Tahap I & $31(64,5 \%)$ & $9(19 \%)$ & $1(2,08 \%)$ & $7(14,5 \%)$ \\
2 & Tahap II & $12(25 \%)$ & $21(43,7 \%)$ & $4(8,3 \%)$ & $11(22,9 \%)$ \\
3 & Tahap III & $17(35,4 \%)$ & $22(45 \%)$ & & $9(19 \%)$ \\
4 & Tahap IV & $25(50 \%)$ & $9(19 \%)$ & $1(2,08 \%)$ & $12(25 \%)$ \\
5 & Tahap V & $35(72 \%)$ & $3(9 \%)$ & $1(2,08 \%)$ & $9(19 \%)$ \\
\hline
\end{tabular}

Pada tahap 1 alur synopsis novel, sebanyak 64,5 \% mendapatkan skor 3, $19 \%$ mendapatkan skor 2, 14.5\% mendapatkan skor 1, dan yang tidak memperoleh nilai ada 14,5 $\%$. Pada tahap 2 alur synopsis novel, siswa yang memperoleh skor 3 sebanyak $25 \%$, skor 2 sebanyak $43,7 \%$, skor 1 sebanyak $8,3 \%$ dan yang tidak memperoleh nilai sebanyak $22.9 \%$. Pada tahap 3 alur synopsis novel, siswa yang memperoleh skor 3 ada 35,4\%, skor 2 sebanyak $45 \%$, skor 1 tidak ada, dan yang tidak memperoleh nilai sebanyak $19 \%$. Pada tahap 4 alur synopsis novel, siswa yang memperoleh skor 3 sebanyak $50 \%$, skor 2 sebanyak $19 \%$, skor 1 sebanyak $2,08 \%$, dan yang tidak memperoleh nilai sebanyak $25 \%$. Pada tahap 5 alur synopsis novel, yang memperoleh skor 3 ada $72 \%$, skor 2 ada $9 \%$, skor 1 ada 2,08\% dan yang tidak memperoleh nilai ada 19\%. Kesimpulan pada tahap 5 alur sinopsis novel hasilnya belum memuaskan. Dari hasil kesimpulan yang diperoleh maka siklus ke 2 masih harus dilaksanakan, agar memperoleh hasil yang maksimal.

\section{Siklus II}

Siklus kedua dilaksanakan pada tanggal 18 Oktober 2016, dengan observer yang sama seperti pada siklus pertama. Pada siklus II ini, guru mengawali pembelajaran dengan mengkondisikan kelas dan menanyakan kehadiran siswa, kegiatan selanjutnya siswa bertanya jawab tentang unsur intrinsik synopsis novel. Guru memberikan contoh cara menganalisis alur dengan cerita yang lain kepada siswa. Setelah itu guru membagi kelompok yang terdiri dari 9 
kelompok. Setiap kelompok terdiri dari 5 sampai 6 orang. Tiap orang dalam tim diberi bagian materi yang berbeda. Selanjutnya siswa mendengarkan sinopsis Novel. Setelah itu siswa membentuk kelompok baru berdasarkan tugas yang sama sehingga menjadi kelompok tim ahli dengan pembagian tugas yang sama dengan siklus sebelumnya.

Selanjutnya dari kelompok yang telah dibagi di awal, siswa yang memperoleh no yang sama bergabung untuk membahas materi yang diberikan guru (kelompok ahli). Lalu berdiskusi untuk memperoleh jawaban. Setelah Siswa yang tadi bernomor sama (kelompok ahli) berdiskusi, tiap anggota kembali ke kelompok awal dan bergantian mengajar teman satu tim mereka tentang bagian yang mereka kuasai, yang lainnya mendengarkan dengan sungguhsungguh.

Selama proses diskusi berlangsung, guru mengamati sambil berkeliling menjaga kemungkinan ada siswa yang masih belum mengerti dan siap untuk memberi penjelasan. Dalam taraf terakhir guru memfokuskan pembelajaran pada tahap pasca analisis, diantaranya dimulai dengan memberikan pertanyaan ringan yang berkaitan dengan hasil menganalisis unsur intrinsik cerpen, kemudian menyuruh wakil masing-masing kelompok untuk membacakan hasilnya, kelompok lain menanggapi.

Siswa yang mendapatkan perlakuan pembelajaran analisis cerpen dengan pendekatan analisis ini berjumlah 48. Pembelajaran analisis cerpen siklus kedua di kelas IX secara umum sudah meningkat, hal ini dapat terlihat dari siswa yang berjumlah 48 tersebut hampir $87,5 \%$ sudah mencapai KKM (Kriteria Ketuntasan Minimal).

Tabel 2. Jumlah Skor Siswa Pada Tiap Tahap Kegiatan Pada Siklus II

\begin{tabular}{llrrrr}
\hline & Tahapan & \multicolumn{3}{r}{} & Jumlah Skor \\
\cline { 3 - 6 } & Alur & 3 & 2 & 1 & 0 \\
\hline 1 & Tahap I & $34(70,8 \%)$ & $12(25 \%)$ & $2(4,16 \%)$ & $0(0 \%)$ \\
2 & Tahap II & $13(27 \%)$ & $30(62, S \%)$ & $3(6,25 \%)$ & $2(4,16 \%)$ \\
3 & Tahap III & $18(37,5 \%)$ & $28(58,3 \%)$ & $2(4,16 \%)$ & $(0 \%)$ \\
4 & Tahap IV & $28(58,3 \%)$ & $13(27 \%)$ & $6(12.5 \%)$ & $1(2,08 \%)$ \\
5 & Tahap V & $38(79,1 \%)$ & $6(12,5 \%)$ & $4(8,3 \%)$ & $0(0 \%)$ \\
\hline
\end{tabular}

Pada tahap 3 alur synopsis novel, siswa yang memperoleh skor 3 ada37,5\%, skor 2 sebanyak $58,3 \%$, skor 1 sebanyak $4,16 \%$, dan yang tidak memperoleh nilai sebanyak $0 \%$. Pada tahap 4 alur synopsis novel, siswa yang memperoleh skor 3 sebanyak 58,3\%, skor 2 sebanyak $27 \%$, skor 1 sebanyak $12,5 \%$, dan yang tidak memperoleh nilai sebanyak $2.08 \%$. Pada tahap 5 alur synopsis novel, yang memperoleh skor 3 ada 79,1\%, skor 2 ada 12,5\%, skor 1 ada 8,3 \% dan yang tidak memperoleh nilai ada $0 \%$. Kesimpulannya seluruh tahap kegiatan alur sinopsis novel hasilnya sudah menunjukkan peningkatan.

\section{Kesimpulan}

Berdasarkan temuan hasil penelitian ada tiga yang dikemukakan dalam penelitian, yakni simpulan tentang peningkatan pemahaman alur sinopsis novel menggunakan teknik diskusi jigsaw pada tahap perencanaan; peningkatan pemahaman alur sinopsis novel menggunakan teknik diskusi jigsaw pada saat pelaksanaan; dan peningkatan pemahaman alur sinopsis novel menggunakan teknik diskusi jigsaw pada tahap refleksi. Berdasarkan temuan-temuan tersebut, ada tiga kategori saran yang perlu disampaikan kepada guru mata pelajaran bahasa Indonesia 
di SMP Negeri 3 Palopo Kota Palopo khususnya dan guru mata pelajaran bahasa Indonesia lain pada umumnya berkaitan dengan hasil penelitian ini.

1. Guru seharusnya menyiapkan perangkat pembelajaran.

2. Guru memotivasi siswa dan dilanjutkan dengan tanya jawab alur sinopsis novel.

3. Teknik diskusi jigsaw adalah teknik yang tepat dalam mengajarkan lima tahap alur sinopsis novel karena dapat menghemat waktu.:

\section{Referensi}

Arikunto, S. (1998). Prosedur Penelitian, Suatu Pendekatan Praktek. Yogyakarta: Rineka Cipta.

Departemen Pendidikan Nasional. (2002a). Pendekatan Kontekstual. Depdiknas: Direktorat PLP.

Departemen Pendidikan Nasional. (2002b). Kegiatan Belajar Mengajar. Jakarta: Puskur. Departemen Pendidikan Nasional. (2003). Manajemen Peningkatan Mutu Berbasis Sekolah, Pembelajaran dan pengajaran Kontekstual. Depdiknas: Direktorat PLP.

Tarigan, H. G. (1998). Menyimak Sebagai Suatu Keterampilan Berbahasa. Bandung: Angkasa.

Wardani. (2002). Penelitian Tindakan Kelas. Jakarta: Universitas Terbuka. 